Права людини в Україні та у зарубіжних країнах:

проблеми теорії та нормативно-правової регламентації

DOI https://doi.org/10.36059/978-966-397-210-7/5-44

Батанов О. В.,

доктор юридичних наук, професор,

провідний науковий співробітник відділу

конституційного права та місцевого самоврядування

Інституту держави і права імені В. М. Корецького

Національної академії наук України,

м. Київ

\title{
МУНІЦИПАЛЬНІ ПРАВА ЛЮДИНИ В УМОВАХ ГЛОБАЛІЗАЦІЇ: ТЕНДЕНЦІЇ СТАНОВЛЕННЯ ТА ОСОБЛИВОСТІ РЕАЛІЗАЦІЇ
}

Анотація. Розділ присвячено дослідженню проблем впливу глобалізації на сучасне муніципальне право та право людини у сфері місцевого самоврядування. Визначено місце місцевого самоврядування та інститутів локальної демократії в окремих європейських державах, європейському континенті загалом та загальноцивілізаційному значенні з погляду прав людини.

Доведено, що стрімкий розвиток муніципального права у сучасних демократіях, тріумфальний рух принципів субсидіарності, регіоналізації та децентралізації, який відбувся у період після другої світової війни в Європі та США, породив тенденцію муніципалізації конституційного життя та правових систем загалом. Свідченням тому $\epsilon$ становлення системи муніципальних прав людини, механізмів їх гарантування та захисту, що $\epsilon$ основою для соціального гомеостазису територіальної громади, який, з одного боку, $\epsilon$ невіддільною характеристикою організації та діяльності місцевого самоврядування на певній території та, з іншого боку, властивістю сучасного муніципального права, яке своєю чергою виконує специфічну гомеостазисну роль у процесах формування соціально-правової державності та громадянського суспільства.

Автор розглядає і аналізує основні положення міжнародноправових актів, що містять європейські правові стандарти 
Права людини в Україні та у зарубіжних країнах:

проблеми теорії та нормативно-правової регламентації

місцевого самоврядування та прав людини, оцінює їх впровадження в украӥнське законодавство. Автор наголошує на необхідності обов'язкового використання європейських правових стандартів у нормотворчості в сфері місцевого самоврядування. Розглядаються сучасні міжнародні договори з погляду їх значення як жерел муніципального права Украӥни.

у процесі дослідження було встановлено, що більшість міжнародних документів розширює діапазон прав жителів членів територіальних громад. Закріплення таких положень на універсальному та регіональному рівні за допомогою рамкових норм міжнародного права свідчить про важливість інституту місцевого самоврядування не тільки у міжнародному аспекті, що характеризується актуалізацією $і$ глобалізацією предметів муніципально-правового

регулювання, але й в національному (внутрішньодержавному) вимірі, ї роллю у процесах формування національного муніципального законодавства, реалізації прав людини, становлення муніципальної влади та ефективної моделі місцевого самоврядування в Україні.

\section{1. Проблеми концептуалізації муніципальних прав людини}

Права людини як найвищий критерій рівня та розвиненості сучасної людської цивілізації виражають найбільш сутнісне у взаємовідносинах як людини з людиною, так і людини зі всіма соціальними спільнотами, в яких вона природним чином перебуває- від сім'ї, народу i нації, соціальної, конфесійної або етнонаціональної належності, професійно-трудової групи, політико-державного об’єднання до людства. У суб'єктивних правах втілені політичні, економічні, соціальні, духовно-ідеологічні, культурні та екологічні основи життєдіяльності людей не тільки в окремих суспільствах та державах, а і в масштабах загальнолюдських.

Права людини сьогодні є однією з ключових проблем, які досліджуються з самих широких та різноманітних позицій з філософсько-гуманістичного погляду, в аспекті сутності 
публічної влади, принципів модернізації політичної та правової системи, проведення соціально-економічної та культурної політики, боротьби з екологічними загрозами, дискримінацією, тероризмом, злочинністю, корупцією тощо. По суті, права людини «відкрили фундаментальну тему про відносини між громадянами та державами» та розкрили «внутрішній конфлікт у міжнародному співтоваристві, який існує між порядком та справедливістю, між суспільством та державою» [1, с. 482].

Так, на думку зарубіжних дослідників, в середині XX ст. в розумінні прав людини «відбулася революція, яка втілила природно-правову доктрину в нормах міжнародного i національного права» [2, с. 261], яка дозволила подивитися на них (права людини - Aвт.), як на «нові стандарти цивілізації» [3]. Без перебільшення, дотримання прав людини вже стало частиною сучасних уявлень про міжнародну легітимність держав. Права людини міцно увійшли до арсеналу правового регулювання всередині держави i не можуть бути проігноровані країнами в їх зовнішній політиці. При цьому «внутрішній порядок реалізації норм про права людини залишається визначальним, а сама тематика цих прав демонструє можливість прогресу в міжнародних відносинах» [4, с. 261-264].

Таким чином, актуалізувалася проблематика прав людини в зв'язку зі здійсненням зовнішніх функцій та конституційноправовим забезпеченням зовнішньополітичної діяльності держави в умовах глобалізації та міждержавної інтеграції, гармонізацією правових систем та формуванням глобального конституціоналізму, а самі права людини стали інструментом, що зближує норми і цінності людства, держав і міжнародного співтовариства.

Водночас слід констатувати, що глобалізаційні процеси у сфері прав людини значною мірою детермінували визнання наприкінці XX - початку XXI ст. ст. на міжнародному рівні місцевого самоврядування як основи будь-якого демократичного ладу, що, з одного боку, значною мірою посилило тенденцію глобалізації доктрини місцевого 
самоврядування та муніципального права, яка особливо рельєфно спостерігається у сучасних євроінтеграційних процесах, та, з іншого боку, вкотре засвідчило той факт, що більшість прав людини реалізується та переважною мірою захищається на локальному рівні, переконливо підтверджуючи вірність одного з девізів Дня Землі - «Мисли глобально, дій локально!».

Вважаємо, що найбільш рельєфно проявляється та знаходить свою апробацію ідея цінності людської особистості, її суб’єктивних прав на локальному рівні - у межах місцевого самоврядування та процесах інституціоналізації муніципальної влади. Адже визнання та становлення місцевого самоврядування, глибокі економічні і політичні перетворення у суспільстві і формування на цій основі нової демократичної державності безпосередньо пов'язані 3 виробленням і практичною реалізацією принципово нових підходів до прав людини, вирішення як загальнодержавних, так і регіональних, а також місцевих проблем у цій сфері.

Саме місцеве самоврядування має створити умови для формування у людському співтоваристві відчуття громадянськості - однієї з тих базових, наріжних рис суспільства, які знаходяться у фундаменті соціуму. Громадянськість - це готовність і здатність людини до активної участі у справах суспільства і держави на основі глибокого усвідомлення своїх прав та обов'язків. Вона $€$ антитезою таких понять, як аполітичність, абсентеїзм, соціально-політична індиферентність, та синонімом соціально-політичної активності, патріотизму. Громадянськість історично пов'язана з ранніми формами демократії, зокрема 3 безпосередньою участю у справах громади і зародженням суспільних відносин полісного типу [5, с.647]. За своєю суттю громадянськість означає ступінь кооперації людей в одне ціле, ступінь відходу від біологічних потреб та руху до потреб соціальних, ступінь спільності, єдності людей. Громадянськість консолідує суспільство, вона знаходиться в основі колективізму, детермінуючи цілісність та монолітність суспільних 
утворень. Громадянськість у її найбільш розвинутій формі передбачає розвиток таких цінностей, як права та свободи, мир та справедливість, відповідальність та соціальна рівність. А це - ключові цінності розвинутого демократичного та громадянського суспільства [6, с. 3].

У цьому аспекті місцеве самоврядування тим самим відіграє вагому роль у процесі формування громадянського суспільства, враховуючи, що усі права, свободи та колективні види соціально-політичної, господарсько-економічної та духовно-культурної активності, різні недержавні прояви суспільного життя людей зароджуються та у кінцевому рахунку реалізуються у територіальних громадах, які утворюють соціальну базу громадянського суспільства.

Протягом тривалої історії свого існування люди прагнули проаналізувати сутність феномена громадянськості та виявити ті чинники, які можна використати як важелі впливу на процеси іï формування та функціонування. На наш погляд, одним із визначальних інструментів формування та функціонування громадянськості $€$ інститут повноцінного місцевого самоврядування. Саме місцеве самоврядування оптимально фіксує у собі як елементарні проблеми людської життєдіяльності, так і політичні, економічні, духовноморальні цінності та соціальні досягнення людства у будьякій галузі суспільного розвитку. Через це відносно невеликі територіальні розміри територіальних громад, локальність діяльності їх органів, здебільшого безпосередній характер взаємовідносин жителів між собою та з органами місцевого самоврядування, природний характер проблем життєдіяльності - усе це в цілому обумовлює особливу муніципальну соціальність. Адже народження людини, іï здоров'я, дорослішання, навчання, працевлаштування, шлюб та сім'я, старіння, смерть - у рамках цих життєвих циклів в основному замикається життєдіяльність місцевого співтовариства.

Також на цьому рівні реалізації публічної влади відбувається діалектичне поєднання волі законодавця 3 конкретними інтересами місцевого населення, яке стає не лише первинним суб'єктом локальних конституційно- 
правових відносин, а й основним суб'єктом управлінських, адміністративно-правових відносин, а також приватних, цивільно-правових відносин, що $є$ однією з характерних рис місцевого самоврядування. У зв'язку з цим варто підтримати позицію, за якою єдиним шляхом здійснення людиною публічної діяльності у рамках будь-якого співтовариства (за обов'язковості нормативного регулювання подібної поведінки) $\epsilon$ реалізація наявних у неї прав та свобод. Через сукупність суб'єктивних прав та свобод можна розглянути весь спектр відносин, що виникають у процесі спільної діяльності людей [7, с. 15].

У зв'язку з цим дослідження прав людини у контексті місцевого самоврядування та конституційно-правових проблем організації та функціонування муніципальної влади, так само як і концептуалізація місцевого самоврядування через призму прав людини та реалізації принципу правовладності, який передбачає панування права у суспільстві та вимагає від держави його втілення у правотворчу та правозастосовну діяльність, зокрема у закони, які за своїм змістом мають бути проникнуті передусім ідеями соціальної справедливості, свободи, рівності тощо, $\epsilon$ одним з найважливіших завдань юридичної науки. Це має не тільки науково-теоретичне значення, а й насамперед практичну значущість: і з погляду розвитку законодавства, і в плані вирішення конкретних питань формування реального місцевого самоврядування та становлення дієздатних територіальних громад, утворення ефективних механізмів забезпечення прав людини.

Слід зазначити, що муніципальні права людини мають відносно самостійне значення як категорія сучасного конституціоналізму, нормативно-правовий інститут місцевого самоврядування, важливий інститут муніципальної демократії та неодмінний атрибут муніципальної влади, який одержує у цій якості конституційне визнання. Адже згідно з Конституцією в Україні визнається та гарантується місцеве самоврядування (ст.7) як право територіальної громади - 
жителів села чи добровільного об’єднання у сільську громаду жителів кількох сіл, селища та міста - самостійно вирішувати питання місцевого значення в межах Конституції і законів України (ч. 1 ст. 140). Причому своє право на участь у місцевому самоврядуванні громадяни України реалізують саме за належністю до відповідних територіальних громад.

Правовий статус людини у системі місцевого самоврядування характеризується органічною єдністю індивідуальних муніципальних суб’єктивних прав, котрі належать кожному жителю окремо і можуть бути реалізовані окремим жителем - членом територіальної громади незалежно від інших ії членів та колективних муніципальних прав, реалізація яких можлива лише за допомогою колективних дій усіх чи більшості жителів - членів територіальної громади. За допомогою цього забезпечується, з одного боку, людиноцентристська орієнтація місцевого самоврядування, а 3 іншого - інтеграція автономних, індивідуалістичних начал муніципальної свободи 3 принципами колективізму, общинності на місцевому рівні організації політичного, господарсько-економічного та соціально-культурного життя [8].

Як своєрідний сплав колективізму й автономності особи, муніципальні права складають у цьому плані важливий елемент нормативного змісту всієї системи місцевого самоврядування, завдяки чому конституційні інститути муніципальної демократії отримують чітку орієнтацію не на адміністративно-державні, а на громадські структури, на пріоритет безпосередніх форм колективної участі жителів у вирішенні питань місцевого значення. А самі інститути місцевого самоврядування в їхньому нормативно-правовому закріпленні просто неможливо розглядати у відриві від муніципальних прав та свобод, які втілюють у собі суб'єктивні фактори функціонування цих інститутів як засобу реалізації кожним окремим жителем - членом територіальної громади своїх індивідуальних можливостей брати участь у вирішенні питань місцевого значення [9, с. 308-309]. 
Така характеристика муніципальних прав людини як інституту місцевого самоврядування та основи легітимності муніципальної влади означає, що нормативно-правове забезпечення муніципальних прав здійснюється (має здійснюватися) не тільки на загальнодержавному, а і на всіх рівнях муніципально-правового регулювання, насамперед локальному (муніципальному). Причому в останньому разі суб'єктивні права жителів - членів територіальних громад повинні закріплюватися не шляхом дублювання відповідних конституційних положень, а у напрямі їхньої конституційної конкретизації, розширення, враховуючи, що перелік конституційних прав та свобод не $\epsilon$ вичерпним. Це може виявлятися, по-перше, у формі конкретизації всіх чи окремих правомочностей, що мають конституційно-правове визнання як права людини; по-друге, встановленням процедури, порядку реалізації відповідного права на певній території; по-третє, закріпленням специфічних муніципальних гарантій здійснення конкретних суб'єктивних прав людини у територіальних громадах.

\section{2. Муніципальні права людини у контексті міжнародних стандартів місцевого самоврядування}

Світовий досвід свідчить, що становлення системи муніципальних прав людини, механізмів їх гарантування та захисту $\epsilon$ основою для соціального гомеостазису територіальної громади, який, з одного боку, є невіддільною характеристикою організації та діяльності місцевого самоврядування на певній території та, з іншого боку, властивістю сучасного муніципального права, яке своєю чергою виконує специфічну гомеостазисну роль у процесах формування соціально-правової державності та громадянського суспільства [10, с. 4].

Місцеве самоврядування, регіоналізація та децентралізація стають тепер провідними принципами демократичної внутрішньої та зовнішньої державної політики та конституційно-правового регулювання у розвинутих країнах. 
У світі все більше відбувається усвідомлення того, що надмірний централізм не змінює держави, а веде до нездатності державного апарату та фактичної девальвації конституційних норм. Так, основна спрямованість принципу субсидіарності у XX ст. полягала у подоланні фашистських і соціалістичних тенденцій, захисті автономії особи та права на самоврядування низових політичних одиниць територіальних громад.

Субсидіарність організації влади тим самим протиставлялася тенденціям у напрямі авторитарної централізованої держави. Субсидіарність розглядалася як передумова устрою, що базується на свободі: держава, яка дотримується принципу субсидіарності, гарантує своїм громадянам свободу і незалежність; вона гарантує місцеве і регіональне самоврядування. Захист свободи через реалізацію принципу субсидіарності нині проголошується однією з традиційних цінностей європейського політичного устрою. 3 одного боку, визнання та гарантування широкого каталогу прав територіальних колективів у демократичних країнах створює умови для формування в них моделі так званої «муніципальної держави», а, з іншого - розвинуте місцеве самоврядування бачиться як «запускаючий інструмент» процесу євроінтеграції, транскордонного та міжконтинентального співробітництва.

Так, наприклад, у Рекомендації Конгресу місцевих i регіональних влад Європи 280 (2010) про роль місцевих і регіональних органів влади в дотриманні прав людини від 19 жовтня 2011 року [11] зазначається, що демократія і права людини є взаємозалежними, причому демократія, в тому числі на місцевому та регіональному рівні, не може існувати без безумовного дотримання прав людини. Уцьому ж документі закріплено, що, по-перше, місцеві і регіональні органи влади повинні виконувати ті обов'язки, пов'язані 3 правами людини, які випливають з міжнародних зобов'язань держав-членів, при цьому тільки в рамках своїх місцевих / регіональних повноважень; по-друге, місцеві та регіональні органи влади $\epsilon$ не тільки представниками центрального 
уряду - вони забезпечують права людини одночасно з тим, як вони здійснюють місцеве самоврядування; по-третє, ефективне управління є таким управлінням, яке засноване на дотриманні прав, при цьому виконання обов'язків, пов'язаних 3 правами людини, $\epsilon$ тим викликом, подолання якого може зміцнити демократію на місцевому рівні; по-четверте, необхідно забезпечувати, щоб місцевим i регіональним органам влади виділялися такі фінансові ресурси, рівень яких дозволить цим органам влади належним чином дотримуватися прав людини і при цьому розглядати i розвивати свою власну діяльність для дотримання цих прав; по-п'яте, необхідно залучати представників місцевих i регіональних органів влади до підготовки національних стратегій, політики та індикаторів у галузі прав людини для того, щоб використовувати їх внесок і прагнути усвідомлення ними відповідальності щодо дотримання прав людини; пошосте, необхідно заохочувати місцеві і регіональні органи влади до того, щоб сприяти дотриманню прав людини через ініціативи просвітницького характеру, а також завдяки здійсненню місцевих і регіональних планів дій; по-сьоме, необхідно сприяти створенню незалежних механізмів розгляду скарг на місцевому та регіональному рівні i, зокрема, створювати незалежні органи, такі як місцеві чи регіональні омбудсмени або уповноважені, здатні знайти відповіді в тих випадках, коли права людини повною мірою не дотримуються, зокрема, під час надання публічних послуг на місцевому рівні тощо. У цих Рекомендаціях Конгрес особливо наголошує, що найважливіше значення для поліпшення становища в галузі прав людини в Європі на всіх рівнях має освіта і прийняття відповідних стандартів. Зокрема, рекомендується заохочення систематичного багатоступеневого діалогу між політичними рівнями всіх держав - членів Ради Європи для того, щоб посилювати правозахисний вимір у сфері місцевого самоврядування, а також посилення поваги до прав людини завдяки професійній підготовці місцевих і регіональних виборних представників і їх співробітників. 
В аспекті формування сучасної доктрини муніципального гуманітарного права колосальне значення мають принципи Декларації щодо забезпечення доброго врядування на місцевому і регіональному рівнях 2005 р. [12, с. 11], 3-поміж яких найважливішим $\epsilon$ принцип інноваційності та відкритості до змін, який дозволятиме територіальним громадам знаходити ефективні шляхи вирішення проблем та використовувати сучасні методи надання послуг, реалізовувати пілотні та випробовувати нові програми і вивчати досвід інших, створювати сприятливий клімат для змін задля досягнення кращих результатів.

Мегатрендом сучасного європейського муніципалізму $є$ принцип сталого розвитку та стратегічної орієнтації, який передбачає врахування інтересів майбутніх поколінь. Потреби майбутніх поколінь беруться до уваги в поточній діяльності місцевого самоврядування. Рішення на місцевому рівні мають прийматися з урахуванням усіх видів витрат, якот екологічні, структурні, фінансові, економічні чи соціальні, з метою запобігання передачі проблем та напруги наступним поколінням. Має існувати розгорнуте та стратегічне бачення майбутнього місцевої громади 3 розумінням того, що $\epsilon$ необхідним для такого розвитку.

Як зазначається у Декларації, ефективна демократія та добре врядування на місцевому і регіональному рівнях $\epsilon$ важливими для забезпечення високого рівня надання послуг населенню та, як наслідок, створення громад «сталого розвитку». Такі громади - це території, де люди бажають жити і працювати як сьогодні, так і в майбутньому. Вони відповідають різноманітним вимогам існуючих та потенційних резидентів, здійснюють охорону природного середовища та роблять відповідний внесок у підвищення якості життя громадян. Ці громади $\epsilon$ безпечними та самодостатніми. Вони забезпечують високий рівень якості послуг, які надаються громадянам.

У цьому контексті особливе звучання має рішення учасників цієї Декларації вважати «забезпечення доброго місцевого і регіонального врядування» глобальним 
завданням, яке має бути досягнуто країнами - членами Ради Європи з метою реагування на виклики, які постали перед європейським співтовариством, та забезпечення законних інтересів громадян.

Ці тенденції значною мірою детерміновані особливістю місцевого самоврядування та муніципальної демократії як відкритої та самостійної системи, яка породжена громадянським суспільством та пов'язана з його політичною системою мережею безкінечних прямих та зворотних зв'язків. Місцеве самоврядування $\epsilon$ органічною частиною оточуючого середовища та втілює у собі всю його багатогранність. Його еволюція - це тривалий, розтягнутий у часі та просторі процес, який складається із сукупності історичних етапів, критеріями виділення яких зазвичай $\epsilon$ різкі, переломні моменти у розвитку суспільства і держави, демократії та владних інститутів, які були викликані сукупністю загально цивілізаційних, державних та регіональних, внутрішніх та зовнішніх, політичних, економічних, соціальних, культурних, екологічних та інших тенденцій і процесів, які детермінують можливість виникнення, визнання та розвитку місцевого самоврядування у конкретній державі.

Саме місцеве самоврядування оптимально фіксує у собі як елементарні проблеми людської життєдіяльності, так і політичні, господарсько-економічні, соціально-культурні, духовно-моральні цінності та соціальні досягнення людства у будь-якій галузі суспільного розвитку. Через це відносно невеликі територіальні розміри територіальних громад, локальність діяльності їх органів, здебільшого безпосередній характер взаємовідносин жителів між собою та з органами місцевого самоврядування, природний характер проблем життєдіяльності - усе це загалом зумовлює особливу муніципальну соціальність. Адже у рамках таких життєвих циклів, як народження людини, іï здоров'я, дорослішання, навчання, працевлаштування, шлюб та сім'я, старіння, смерть, замикається життєдіяльність місцевого співтовариства. 
Через це сьогодні особливо актуалізується питання про процеси визнання, становлення та перманентного розвитку муніципалізму, місцевого самоврядування та інститутів локальної демократії в окремих європейських державах, європейському континенті загалом та загальноцивілізаційному значенні як з погляду формування українського, європейського та світового конституціоналізму, процесів демократизації, глобалізації та європейської міждержавної інтеграції, так і з погляду формування сучасної ефективної моделі міжнародного гуманітарного права, конституційного гуманітарного права та муніципального гуманітарного права. Саме у цьому аспекті й варто розуміти зафіксований у преамбулі Європейської Хартії місцевого самоврядування [13] мотив їі прийняття: «охорона i посилення місцевого самоврядування в різних країнах Європи є важливим внеском у розбудову Європи на принципах демократії $\mathrm{i}$ децентралізації влади».

Фундаментальні принципи демократії, верховенства прав людини, визнання місцевого самоврядування, а також акумульований світовий досвід організації та функціонування муніципальної влади, знайшли своє закріплення у так званих міжнародно-правових стандартах місцевого самоврядування, які відіграють колосальну роль у процесах формування європейського муніципального права, нормативному регулюванні організації та функціонуванні місцевого самоврядування, як в окремих зарубіжних країнах, так і на регіональному і глобальному рівнях, а також становлення багаторівневої системи захисту прав людини, у тому числі муніципального правозахисного механізму.

у практиці муніципального будівництва найбільш важливим $\epsilon$ не тільки загальне визнання, рецепція, ратифікація, імплементація та законодавче закріплення стандартів місцевого самоврядування, але й реальний та ефективний режим їх дотримання та захисту. Саме для того щоб муніципальні права людини не залишалися декларативними, необхідний конкретний внутрішньодержавний механізм здійснення міжнародних стандартів 
місцевого самоврядування. Формування такого механізму, налагодження його елементів залишається однією 3 найбільш актуальних проблем удосконалення муніципального законодавства.

Міжнародні стандарти муніципальної демократії відіграють значну роль у процесах становлення муніципалізму, соціально-правової державності та реалізації прав місцевого самоврядування в сучасному світі. Такими стандартами $\epsilon$ міжнародно-правові норми, що регламентують основні принципи, форми і методи здійснення муніципальної діяльності, прийняті державами світу в рамках міжнародних міждержавних організацій. Особливостями міжнародних стандартів у цій сфері $\epsilon$ те, що вони регламентують спільно вироблені державами концептуальні підходи і міжнародно-легальні принципи становлення, формування i функціонування інституту місцевого самоврядування на території конкретних держав.

Закріплення таких положень на універсальному та регіональному рівні за допомогою рамкових норм міжнародного права свідчить про важливість інституту місцевого самоврядування не тільки у міжнародному аспекті, що характеризується актуалізацією і глобалізацією предметів муніципально-правового регулювання, але й у національному (внутрішньодержавному) вимірі, їх роллю у процесах формування національного муніципального законодавства, реалізації прав людини, становлення муніципальної влади та ефективної моделі місцевого самоврядування в Україні.

У сучасних міжнародно-правових стандартах локальної демократії доволі рельєфно відображене ії значення в умовах глобалізації та міждержавної інтеграції, зокрема, безпосередньо зазначається, що міждержавні угоди, які укладаються у сфері місцевого самоврядування, прямо зумовлені прагненням до досягнення «більш сильної єдності» між державами (Преамбула Європейської Хартії місцевого самоврядування [13]); стверджується, що вони приймаються зі спеціальною метою - «бути для всіх націй стандартом, до 
якого слід прагнути, намагаючись досягти більш демократичного процесу, поліпшуючи, таким чином, добробут свого населення» (Преамбула Всесвітньої Декларації місцевого самоврядування [14]) або зазначається, що метою їх ухвалення $\epsilon$ «сприяння економічному та соціальному прогресу прикордонних регіонів і зміцненню солідарності, яка об'єднує народи Європи» (Преамбула Європейської рамкової конвенції про транскордонне співробітництво між територіальними общинами або властями [15]).

У преамбулі Декларації щодо забезпечення доброго врядування на місцевому і регіональному рівнях [12, с.11] зазначається, що «завдання, які сьогодні постали перед Європою, не $є$ завданнями виключно для європейських країн - вони $\epsilon$ глобальними та мають паралельно вирішуватись як на міжнародному, так і на місцевому рівнях».

Преамбула проекту Всесвітньої хартії місцевого самоврядування [14] взагалі починається з нагадування, що згідно з принципом, який закріплений у Загальній декларації прав людини, а саме в іï статті 21, воля народу має бути основою влади органів управління всіх рівнів, а місцева демократія $\epsilon$ основоположним правом.

Враховуючи, що «місцеве самоврядування $\epsilon$ необхідним елементом демократичної організації державного та суспільного життя кожної держави - учасниці СНД» та «усвідомлюючи необхідність спільних зусиль усіх держав учасниць СНД у підтримку реалізації демократичних принципів місцевого самоврядування та створення його дієвих гарантій», було прийнято і Декларацію про принципи місцевого самоврядування у державах - учасницях СНД [16].

Такого роду гуманістична спрямованість місцевого самоврядування та його людиновимірний характер вказує на колосальне значення муніципальної демократії в умовах глобалізації, як з погляду вирішення питань місцевого значення, так і з погляду реалізації прав людини. 
Права людини в Україні та у зарубіжних країнах:

проблеми теорії та нормативно-правової регламентації

\section{3. Концептуальні засади та прикладні проблеми реалізації муніципальних прав людини}

Говорячи про конкретний вплив інститутів муніципального права та муніципальної влади на розвиток та реалізацію окремих видів прав людини, необхідно диференційовано підходити до окремих їхніх груп, аналізу нормативного змісту i функціональних зв'язків 3 інститутами місцевого самоврядування та муніципальної демократії. Не ставлячи за завдання вивести якісь нові класифікаційні варіанти аналізу прав та свобод, у тому числі в зв'язку з їхнім впливом на розвиток місцевого самоврядування, спробуємо розглянути особливості реалізації окремих видів муніципальних прав людини виходячи з із їх суб'єктно-об'єктної характеристики, насамперед, з одного боку, в аспекті ролі та значення у процесах функціонування місцевого самоврядування окремих категорій жителів - членів територіальних громад, та, 3 іншого боку, об’єктів місцевого значення та сфер життєдіяльності муніципальних спільнот (політичної, економічної, соціальної, культурної та інших), в межах яких проходить життя людини, реалізуються суб'єктивні потреби та інтереси, що зумовлюють характерні муніципальноправові відносини тощо. Відповідно, виділяючи окремі види та групи муніципальних прав людини, відзначимо найбільш істотні взаємозв'язки цих прав 3 інститутами місцевого самоврядування.

Прикладом тому є положення Стамбульської декларації з проблем поселень людей [17], де, стосовно до конституційного права на безпечне для життя і здоров'я довкілля йдеться про його муніципально-правову модифікацію в обов'язок держав-учасників цього документу забезпечити «особливі потреби жінок, дітей та молоді у надійних, здорових і безпечних умовах життя». 3 цією метою, держави-учасниці цього документу взяли на себе зобов'язання «добиватися покращення умов життя в населених пунктах такими засобами, які відповідають місцевим потребам та реальностям», а також визнали 
«необхідність аналізу глобальних економічних, соціальних та екологічних тенденцій в цілях утворення більш досконалого середовища мешкання для всіх людей». Також державиучасники зобов'язуються «сприяти наданню повноцінного доступу людям 3 фізичними вадами, а також статевого рівноправ'я для участі в політичних акціях, програмах та проектах 3 питань житла та життєздатного розвитку поселень людей» (п. 7).

Про важливість місцевого самоврядування та муніципального права в умовах глобалізації та міждержавної інтеграції свідчать положення Екологічної Угоди Міст від 5 червня 2005 року [18]. Розглядаючи даний документ як «синергетичне продовження зусиль по сприянню стабільності розвитку, посиленню нестійких економік, підвищенню суспільної активності, і захисту природних систем планети», сторони - мери багатьох великих міст світу (у т. ч. і м. Києва), які підписали його, виходили, у першу чергу, 3 того, що «більшість населення планети зараз живе в містах і що безперервна урбанізація приведе до того, що один мільйон людей буде переміщуватись до міст кожного тижня, створюючи тим самим нову низку екологічних проблем i можливостей». Вказуючи на те, що мери міст зі всього світу мають «унікальну можливість керувати розвитком належним чином підтримуваних міських центрів, в основі чого лежатимуть відповідні культурні і економічні місцеві заходи», сторони, які підписали цей документ, «зібралися разом для того, щоб вписати новий розділ в історію всесвітньої кооперації» та взяли на себе «зобов'язання підвищити рівень партнерських стосунків і побудувати екологічно стабільне, економічно динамічне, і соціально справедливе майбутнє для наших міських жителів».

Доволі рельєфно ілюструє проблему реалізації права на участь у місцевому самоврядуванні в умовах глобалізації екстраполяція на локальний рівень загальновизнаного у сучасному світі принципу рівності чоловіка та жінки. Досягнення гендерної рівності неможливе без наявності відповідного механізму реалізації прав і свобод, а зміни в 
Права людини в Україні та у зарубіжних країнах:

проблеми теорії та нормативно-правової регламентації

суспільстві, звичайно, відбуваються через політичний процес, монопольними власниками якого все ще залишаються переважно чоловіки. Втім зміни у суспільстві, у тому числі й у їх гендерному вимірі, можуть відбутися лише за умовою, якщо такі зміни відбудуться у територіальних громадах. У сучасному міжнародному політичному й соціологічному дискурсі поняття місцевого самоврядування, децентралізації та функціонування територіальних громад досить часто розглядають у зв'язку з поняттям гендеру [19]. При цьому увага акцентується на тому, що «впровадження гендеру» означає не просто додавання «жіночого компоненту» до проектів та програм. Це, насамперед, аналіз і врахування різних умов та вимог щодо жінок і чоловіків, тих ролей, які вони відіграють у соціумі в цілому, та територіальних громадах і процесах децентралізації публічної влади, зокрема. Однією з найбільш гендерно-чутливих проблем, характерних для сучасної України, є обмежений їх доступ жінок до влади в цілому та муніципальної влади, зокрема. Адже, незважаючи на те, що жінки в Україні де-юре мають рівні права 3 чоловіками, де-факто вони продовжують зазнавати дискримінації, зокрема і в політичній сфері, оскільки недостатньо представлені на рівні прийняття політичних рішень [20, с. 18-19]. Щоправда, на відміну від національного рівня, ситуація 3 представленістю жіночого досвіду на місцевому рівні $\epsilon$ дещо кращою та такою, що має позитивну тенденцію [21]. Комітет виборців України проаналізував результати виборів до міських рад м. Києва та міст-обласних центрів. За даними з 22 міських рад, обрано 214 депутаток та 969 депутатів. Таким чином, середній рівень представництва жінок в міських радах - 18,1\%. 3214 депутаток, обраних за результатами виборів, 13 (або 6,1\%) були лідерами партійних списків. Для порівняння, серед 5552 жінок-кандидаток в міські ради, було 58 лідерів списків, тобто 1\%. 3 одного боку, це свідчить про те, що закріплення за жінками місць в прохідній частині списку сприяє проходженню в місцеві ради. 3 іншого боку, 93,9\% обраних жінок-депутаток отримали мандат завдяки підтримці виборців, а не закріпленому місцю 
в списку. Тобто в суспільстві $є$ потенціал для підтримки жінок на обрані посади, навіть за умови відносно меншого за чоловіків-кандидатів ресурсного забезпечення агітації. В цілому, зазначають експерти, в порівнянні зі складом міських рад попереднього скликання, ситуація з гендерним балансом покращилась в 11 з 22 радах. Поріг в 30\% було подолано тільки в одній міській раді - а саме, в Чернігівській. При цьому, робиться висновок, що низький рівень представництва жінок в місцевих органах влади, що обираються, не пов'язаний із небажанням жінок йти в політику.

Цікавими та доволі показовими у гендерному вимірі місцевого самоврядування $\epsilon$ й інші висновки [22]. Так, оскільки діяльність місцевої влади базується на традиційно жіночих інтересах: добробут, освіта, чистота довкілля, охорона здоров'я та дозвілля, то й до відповідних структур жінок задіяли нарівні 3 чоловіками. 3 боку гендерної перспективи, органи місцевого самоврядування - це найбільш наближений та доступний рівень управління для жінок. Це пояснює той факт, що відсоток жінок у радах місцевого рівня сьогодні набагато вищий, ніж у Верховній Раді. Це підтверджують і відповідні статистичні дані, які свідчать, що чим нижчий рівень органів влади, тим вони доступніші для жінок.

У цьому аспекті доволі цікавим та ілюстративним $\epsilon$ зарубіжний досвід. Так, згідно з даними організації «Об’єднані міста і місцеві уряди» (UCLG) у світі лише 5\% жінок-мерів та 20\% жінок-депутатів. Лише 10 зі 195 світових столиць очолюють жінки, що складає 5,1\%. Трошки вищим $\epsilon$ рівень представництва жінок-мерів у містах-мільйонниках 29 жінок з 493 мерів міст, що складає 6,1\%. За даними Спілки асоціацій місцевих органів влади південно-східної Європи (NALAS), яка включає в себе 14 повних членів національних асоціацій МСB, 7 - асоційованих членів, 9000 - органів місцевої влади, які представляють 80 млн мешканців, лише 8,4 \% міських голів в південносхідній Європі - це жінки, 91,6\% - чоловіки; 29,9\% 
депутатів в південно-східній Європі - це жінки, 70,1\% - це чоловіки. Стурбовані цією ситуацією на Генеральній асамблеї Спілки асоціацій місцевих органів влади південносхідної Європи (Пріштіна, Сербія 14-15 квітня 2016 р.) делегати спілки прийняли Положення про сприяння гендерній рівності на місцевому рівні [23].

$€$ й інші приклади посиленої уваги світового співтовариства до проблем гендерної рівності у територіальних громадах. Так, країни-учасники Декларації про міста та інші населені пункти в новому тисячолітті [24], вважаючи за необхідне за допомогою відповідних механізмів забезпечити щоб жінки відігравали ефективну роль у прийнятті рішень місцевими органами влади (п. 39), заявили про свою дотриманість меті забезпечення гендерної рівності у розвитку населених пунктів та сповнені рішучості підтримувати гендерну рівність та розширення можливостей жінок у якості ефективних способів боротьби з бідністю та стимулювання розвитку населених пунктів, які будуть по справжньому стійкими. «Ми далі беремо на себе зобов'язання формулювати та зміцнювати політику та практику забезпечення повної та рівноправної участі жінок у плануванні населених пунктів та прийнятті рішень», - зазначалося у Декларації (п. 44).

У гендерному вимірі існування та перспективного розвитку місцевого самоврядування з позиції міжнародних муніципальних стандартів колосальне значення набувають положення Всесвітньої декларації Міжнародного союзу місцевих органів влади про роль жінки у місцевому самоврядуванні [25]. Так, у частині 10 цього документу закріплено, що система місцевого управління займає унікальне положення з точки зору сприяння боротьбі за гендерну рівність на глобальному рівні та може зробити серйозний вплив на положення жінок та ситуація в галузі гендерної рівності в усьому світі; представляє собою рівень керівництва, найбільш близький до громадян, діючи у якості надання послуг та працедавця. У частині 12 документу вказується й наступний мотив розробки цього 
документу: «з метою утворення стійких, заснованих на принципах рівноправ'я та демократії місцевих органів управління, де б жінки і чоловіки мали рівний доступ до процесу прийняття рішень, рівний доступ до послуг i рівний статус в процесі надання цих послуг, гендерна проблематика має бути включеною у всі сфери директивної й управлінської діяльності місцевих органів управління».

Група спеціалістів з гендерного підходу Ради Європи (1995-1998) [26] визначила гендерний підхід як «(ре)організацію, покращення, розвиток та оцінка політичних процесів таким чином, аби аспект гендерної рівності та перспективи був врахований в усіх напрямках політики та на усіх рівнях та етапах при залученні усіх сторін в процесі розвитку політики». Рекомендація 148(2004) Конгресу про гендерний підхід на місцевому та регіональному рівнях наголошує на важливості механізмів гендерної рівності як визнаної системи підтримки, спрямованої допомогти тим особам, яких залучено до розробки політики й надання послуг, зрозуміти й реалізувати концепцію гендерної рівності, а також спосіб, у який належить відстежувати прогрес та заохочувати до звітності осіб, залучених до робіт [27].

Разом з Рекомендацією 148(2004), Резолюція 176(2004) Конгресу закликає органи місцевих та регіональних влад підтримувати гендерну рівність на гендерний підхід та застосовувати в цьому напрямку на практиці відповідні інструменти та механізми, особливо статистику 3 розподілом за статтю [28].

Також, у сучасній Європі одним 3 ефективних інструментів гендерного підходу $\epsilon$ гендерно чутливе бюджетування. Так, Резолюція 405(2016) Конгресу щодо гендерно чутливого бюджетування [29] стимулює національні, регіональні та місцеві органи влади пропонувати та впроваджувати відповідні інструменти та процедури. Особливо ця резолюція наголошує на проведенні місцевими та регіональними органами влади 
аналізу бюджету з розбиттям за статтю, обміні думками та кращими практиками с містами та регіонами, які вже застосовують методи гендерно чутливого бюджетування та планувати механізми консультування та залучення громадського суспільства.

Знаковою є Резолюція 391(2915) Конгресу про боротьбу із зростаючою бідністю серед жінок: відповідальність місцевих та регіональних органів влади [30], яка спонукає країни-члени враховувати гендерний аспект бідності та брати до уваги зростаючий рівень бідності серед жінок в процесі боротьби з бідністю.

Можна згадати й Європейську хартію рівності жінок і чоловіків на місцевому рівні [31], розроблену у 2006 році Радою європейських муніципалітетів і регіонів (CEMR). Європейська хартія, як інструмент політичної волі, дуже корисна для органів місцевого самоврядування. Підписана міськими головами, ця Хартія надає чіткі рекомендації органам місцевого самоврядування щодо заходів в рамках їх компетенції, які потрібно в проваджувати для забезпечення рівноправ'я між чоловіками та жінками (а також національними меншинами, недієздатними особами тощо). Крім сприяння гендерній рівності та рівним можливостям (кампанії, громадський простір, застереження), у документі також зосереджено увагу на важливості виконання гендерного аналізу місцевих рішень/політики, консультацій з чоловіками та жінками стосовно різних питань, а також розвитку гендерно чутливих соціальних служб. Згідно з цим документом, органи місцевого самоврядування зобов'язані розробити план заходів з впровадження політики гендерної рівності а також заохочуються до розробки та обміну кращими практиками між містами та регіонами.

Ці та інші міжнародні документи 3 питань гендерної рівності передбачають, що основні напрями діяльності щодо впровадження гендерної рівності (на національному, регіональному чи місцевому рівні) повинні включати: професійну підготовку жінок і нарощування їх потенціалу; 
підвищення рівня поінформованості та зміна уявлень громадськості щодо гендерних ролей чоловіків та жінок; створення мережі партнерських організацій з підтримки просування жінок у сферу політики й управління. Інші можливості підвищення участі жінок у політичному житті та управлінні, в першу чергу, на місцевому рівні, передбачають: використання бюджету як важливого політичного інструменту; посилення роботи на місцях; пропаганда гендерної рівності і агітація за неї; проведення гендерних досліджень, використання різних показників; реформа виборчої і політичної системи; зміна ролі жінок в політиці.

Також міжнародні документи та результати різних національних досліджень свідчать про необхідність застосування гендеру до публічного врядування з питань послуг з водопостачання, яка означає, що місцеві органи влади мають бути відповідальними, чутливими, задіяними та прозорими як щодо чоловіків, так і щодо жінок при плануванні нових систем 3 водопостачання, при їх експлуатації та алокації ресурсів на своїй території. Нерідко в публікаціях зустрічається висновок, що надання послуг водопостачання у домогосподарства $\epsilon$ високо релевантним проявом стосунків між державою та індивідуумами, які по-різному впливають на чоловіків і жінок. У зв'язку з цим рекомендується проводити як аналіз гендерної ситуації на рівні спільнот, так і на рівні домогосподарств, де існує глибоко усталений традиційний розподіл праці між жінками та чоловіками [32, с. 37-38].

Міжнародні та національні структури, які опікуються питаннями гендерної рівності у місцевому самоврядуванні, закликають застосовувати принцип врахування гендерної проблематики шляхом включення її в усі стратегії, програми та заходи з надання послуг в рамках окремих органів місцевого самоврядування та їх асоціацій на національному, регіональному та міжнародному рівнях, розробляти методи моніторингу і оцінки такого роду роботи; вишукувати нові шляхи забезпечення того, щоб 
жінки були представлені в процесі управління на місцях і активно брали участь в ньому, використовуючи формальні, а також неформальні засоби; зміцнювати співробітництво на міжнародному та національному рівнях між органами місцевого самоврядування та їх асоціаціями на національному, регіональному та міжнародному рівнях 3 метою розширення обміну досвідом; розробляти програми і стратегії, які сприяють усуненню перешкод на шляху участі жінок в процесі прийняття рішень на місцевому рівні; розробляти, здійснювати і контролювати плани дій по сприянню створенню рівних можливостей для роботи в муніципальних органах, включаючи рівні можливості щодо найму, просування по службі, винагороди, а також рівні умови праці; домагатися зміни поглядів, що стосуються гендерних питань, шляхом підвищення рівня інформованості в рамках системи освіти, а також політичної та адміністративної структури місцевих органів управління; активно взаємодіяти 3 іншими членами суспільства, включаючи національні гендерні структури і організації, приватний сектор, неурядові організації, професійні об'єднання, жіночі організації, науково-дослідні установи та профспілки тощо.

Розглядаючи гендерні стереотипи та дискримінаційні практики у місцевому самоврядуванні за ознакою статі своєрідними аномаліями у муніципально-правовій сфері, вважаємо, що місцеве самоврядування $\epsilon$ невід'ємною частиною національної структури публічного владарювання у демократичній державі та являє собою рівень влади й управління, що $є$ найбільш близьким до громадян, i, в силу цього, спроможним найкращим чином включати жінок в процес прийняття рішень щодо умов життя територіальних громад та питань місцевого значення, використовувати їх знання, досвід та можливості для сприяння стійкому розвитку територіальних громад. Звідси можна зробити висновок, що місцеве самоврядування відноситься до числа найбільш гендерно 
чутливих інститутів демократії. Наведені вище проблеми міжнародно-правового та конституційно-правового забезпечення принципу гендерної рівності у місцевому самоврядуванні, нажаль, ще не стали предметом пильної уваги вітчизняних вчених-конституціоналістів. Враховуючи серйозні виклики та загрози, які виникають у сфері реалізації та захисту прав людини в цілому, наукова громадськість має висловлювати свою виважену позицію щодо актуальних проблем інституціоналізації та конституювання гендерних прав в цілому та їх послідовної реалізації у житті територіальних громад та діяльності органів місцевого самоврядування, зокрема.

Ці та інші приклади свідчать, що міжнародно-правове визнання існування у людини невідчужуваних природних прав, закріплене за допомогою прийняття міжнародних норм профільного характеру, що містяться в міжнародних актах, привело до формування і чіткого визначення їх мінімуму, незнижуваного на національному рівні. У цьому аспекті місцеве самоврядування, як феномен сучасного конституціоналізму та універсальна форма реалізації практично всіх прав людини, об'єктивно виступає фактором інтернаціоналізації національного та конституціоналізації міжнародного правопорядків [33]. По суті сьогодні можна спостерігати глобалізацію доктрини муніципального права та місцевого самоврядування, а також прав людини у муніципальноправовому вимірі їх реалізації.

На наш погляд, в умовах глобалізації, інформатизації та розвитку сучасних засобів комунікації муніципальне право стає нормативно-правовим інструментом реалізації одного 3 головних завдань сучасності - поєднання в єдине ціле інтересів держави, суспільства та особи, оскільки головний сенс та сутність місцевого самоврядування полягають у тому, щоб на рівні кожної окремо взятої особи здійснювати гармонізацію прав та свобод людини і громадянина 3 інтересами держави та суспільства. Уцьому контексті, 
варто відзначити й те, що серед багатьох турбот сучасного суспільства одна 3 найгостріших проблем - проблема відчуження людей, ксенофобія, патологічний егоцентризм та індивідуалізм. У поєднанні 3 гострими кризовими явищами в економічному та політичному житті ця проблема спричиняє існування цілої низки песимістичних поглядів на долю людства взагалі, свідченням чого $\epsilon$ офіційно визнана ООН «стратегія виживання». Людська цивілізація протягом своєї історії нагромадила цінний досвід подолання ворожнечі і взаємоненависті, досвід, який акумулювався в такій соціальній та духовній цінності, як людська солідарність. Головним засобом забезпечення солідарності стає культура людських взаємин, цивілізований спосіб спілкування, або так звана «комунікативна культура» [34, с. 1]. В змістовно-термінологічному сенсі поняття «комунікація» перебуває в одному ряду 3 близькими за змістом поняттями «взаємодія» (взаємини), «людські стосунки», «взаємообумовленість», «взаємовплив» тощо, зміст яких оптимально характеризує процеси самоорганізації людей за місцем проживання.

Культура комунікацій, що базується на принципах пріоритету соціальних, тобто суспільно-значимих інтересів, діалогічних, рівноправних стосунках, синтезі індивідуальних свобод та спільної відповідальності, перетворюється на рубежі XX та XXI століть на одну 3 домінант суспільного життя, на загальнолюдську норму мислення та поведінки, на «світову етику». У цьому аспекті необхідно усвідомлювати, що перспективи модернізації соціально-економічної, політичної, правової, духовнокультурної та інших систем українського суспільства у даний час визначаються не тільки об'єктивними закономірностями інноваційного розвитку держав в умовах глобалізації та європейської міждержавної інтеграції, процесами зближення правових систем сучасності, а й необхідністю врахування та гармонізації у процесі формування вітчизняного конституціоналізму локального-особистісного фактора та різноманітних 
особистісних та колективних, місцевих, регіональних i державних інтересів, розмаїття історичних, національнокультурних та інших особливостей розвитку територіальних громад як первинної суб'єктної основи муніципальної влади, яка у сучасному світі закономірно визнається основою будь-якого демократичного ладу.

Ілюстративними у цьому аспекті $\epsilon$ положення Всесвітньої декларації місцевого самоврядування [14] про те, що «зміцнення місцевої влади зміцнює націю в цілому шляхом забезпечення ефективнішої та демократичнішої суспільної політики», а також зафіксовані у преамбулі Європейської ландшафтної конвенції [35] мотиви прийняття цього документу, що орієнтують державиучасниці на те, що вони повинні усвідомити, що «ландшафт сприяє формуванню місцевих культур і $\epsilon$ основним компонентом європейської природної та культурної спадщини, який сприяє добробуту людей та консолідації європейської ідентичності» та необхідність визнання того, що «ландшафт $\epsilon$ важливою складовою якості життя людини всюди: в містах і сільській місцевості, у занедбаній місцевості та місцевості високої якості, в місцевості виняткової краси та в звичайній місцевості».

Цікавими $€$ й положення Переглянутої Європейської Хартії щодо участі молоді у громадському житті на місцевому та регіональному рівнях, прийнятої Конгресом місцевих та регіональних влад Ради Європи на 10-й пленарній сесії 21 травня 2003 р. [36, с. 178, 181-182], у якій вказується, що «активна участь молодих людей у процесі ухвалення рішень та громадській діяльності на місцевому і регіональному рівнях має важливе значення, якщо ми дійсно маємо намір побудувати більш демократичне, солідарне і процвітаюче суспільство. ... Підтримуючи і стимулюючи участь молоді у суспільному житті, місцеві і регіональні влади мають сприяти соціальній інтеграції молодих людей, допомагаючи їм долати не лише проблеми та труднощі, але й знаходити відповідь на виклики сучасного суспільства, в якому часто домінують егоїзм та 
індивідуалізм. Проте для того, щоб участь молоді в суспільному житті на місцевому і регіональному рівнях була успішною, постійною і осмисленою, потрібно мати щось більше, ніж розвиток політичних чи адміністративних систем. Будь-яку політику чи дію, покликану активізувати участь молоді в житті суспільства, має забезпечувати культурне середовище, що поважає молодь і враховує різноманітні потреби, обставини та сподівання молодих людей».

У контексті порушеної нами тематики варто звернути увагу на положення частини I.5 «Політика мобільності і обмінів» цього документу, у якій вказується, що місцевим і регіональним владам слід підтримувати об'єднання чи групи, що виступають за підвищення мобільності молодих людей (молодих працівників, студентів або добровольців) через політику обмінів і розвивати політику зв'язків та усвідомлення себе громадянами Європи. Місцевим i регіональним владам слід заохочувати молодих людей, їх організації та навчальні заклади до активної участі в міжнародній діяльності, усіх видах обмінів та роботі в європейських мережах. Місцеві влади повинні бути готовими надати їм фінансову підтримку 3 метою сприяння вивченню мов і міжкультурним обмінам, а також обміну досвідом.

Важливою $є$ роль місцевого самоврядування у реалізації та захисті прав осіб з особливими потребами. Так, одними 3 мотивів прийняття Конвенції про права осіб з інвалідністю [37], стало розуміння того, що інвалідність - це поняття, яке еволюціонує, і що інвалідність є результатом взаємодії, яка відбувається між людьми, які мають порушення здоров'я, і відносницькими та середовищними бар'єрами і яка заважає їхній повній та ефективній участі в житті суспільства нарівні з іншими, а також визнання цінного нинішнього і потенційного внеску осіб з інвалідністю у загальний добробут i багатоманітність їхніх місцевих товариств i ту обставину, що сприяння повному здійсненню особами з інвалідністю своїх прав людини та 
основоположних свобод, а також повноцінній участі осіб з інвалідністю дасть змогу зміцнити в них почуття причетності й досягти значних успіхів у людському, соціальному та економічному розвитку суспільства та викоріненні бідності (Преамбула).

Відповідно до ст. 19 цього документу, яка має назву «Самостійний спосіб життя й залучення до місцевої спільноти», держави-учасниці цієї Конвенції визнають рівне право всіх осіб з інвалідністю жити у звичайних місцях проживання, коли варіанти вибору $\epsilon$ рівними 3 іншими людьми, i вживають ефективних i належних заходів для того, щоб сприяти повній реалізації особами з інвалідністю цього права та повному включенню й залученню їх до місцевої спільноти, зокрема забезпечуючи, щоб: а) особи з інвалідністю мали можливість вибирати нарівні з іншими людьми своє місце проживання й те, де й 3 ким проживати, і не були зобов'язані проживати в якихось визначених житлових умовах; b) особи 3 інвалідністю мали доступ до різного роду послуг, що надаються вдома, за місцем проживання, та інших допоміжних послуг на базі місцевої спільноти, зокрема персональної допомоги, необхідної для підтримки життя в місцевій спільноті й уключення до неї, та 3 метою недопущення ізоляції або сегрегації від місцевої спільноти; c) послуги та об'єкти колективного користування, призначені для населення в цілому, були рівною мірою доступні для осіб з інвалідністю і відповідали їхнім потребам.

Свідченням перманентного розширення муніципальних прав людини $є$ європейська практика їх надання постійнім мешканцям-іноземцям. Так, ще у 1992 р. у рамках Ради Європи була прийнята Європейська конвенція про участь іноземців у суспільному житті на місцевому рівні [38], якою встановлюється принцип, згідно 3 яким іноземним громадянам гарантуються громадянські та політичні права, включно з правом брати участь у виборах. Так, згідно частини першої ст. 6 цього документу передба- 
Права людини в Україні та у зарубіжних країнах:

проблеми теорії та нормативно-правової регламентації

чається зобов'язання держав-учасників Конвенції надати кожному постійному мешканцю-іноземцю право голосувати та висувати свою кандидатуру на виборах до органів місцевого самоврядування, якщо він задовольняє тим правовим вимогам, які пред'являються громадянам i, крім того, на законних підставах постійно мешкає у відповідній державі упродовж п'яти років, що передують виборам. Також встановлюється, що ценз осілості, передбачений у статті 6, може становити і менший період (ст. 7).

Такий підхід є свідченням того, що у державах сучасної Європи відбувається кардинальне переосмислення сутності та змісту конституційного права на участь в управлінні публічними справами у розрізі муніципальної демократії: якщо держава має справи громадянами, іноземцями, особами без громадянства, біженцями, то місцеве самоврядування - 3 мешканцями. Держави-члени Ради Європи, які підписали Європейську хартію місцевого самоврядування, вважають, що право громадян брати участь в управлінні державними та суспільними справами належить до загальних для всіх держав демократичних приписів, і це право безпосередньо може бути здійснено саме на місцевому рівні.

Стратегічний момент у розумінні цієї проблеми полягає в еволюції загального конституційного правового статусу людини в місцевому самоврядуванні. На рівні територіальних громад цілком змінюється система координат, яка панує в державі щодо прав людини. 3 рівня «громадянин - держава» права людини переходять на рівень «мешканець - орган місцевого самоврядування» та трансформуються у муніципальні права особи.

Цей підхід, який існує в країнах сучасної Європи (наприклад у Данії, Бельгії, Польщі, Латвії), безпосередньо пов'язаний із визнанням відмінності різних статусів публічної влади: державної влади як представника суспільства в цілому, його політичної влади та місцевого самоврядування - як публічної влади територіального 
колективу. Так, наприклад, згідно з частиною 2 §70 Конституції Угорської Республіки 1949 року на виборах до місцевого самоврядування та виборах міського голови виборче право, а також право участі в місцевому референдумі та місцевій народній ініціативі згідно особливого закону - належить також не угорським громадянам, які проживають на території Угорської Республіки як іммігранти, якщо вони на день виборів або, відповідно, референдуму, знаходяться на території країни. Згідно ст. 130 Конституції Королівства Нідерланди 1983 року право участі в виборах муніципальних рад та бути обраним до їх складу може бути надано Актом парламенту особам, які не $\epsilon$ громадянами Нідерландів, але постійно проживають в муніципалітетах, якщо вони відповідають тим саме виборчим цензам, що і громадяни Нідерландів.

Такий підхід є свідченням підвищення ролі муніципальнотериторіального чинника в житті суспільства, створенням дієздатних територіальних громад, підтвердженням демократичних намірів національних держав та їх особливої уваги саме до мешканців певних територій.

Однією з найбільш складних, суперечливих та таких, які вкрай неоднозначно сприймаються та вирішуються у сучасному світі, $\epsilon$ проблема прав сексуальних меншин. Попри те, що майже усе XX ст. пройшло під прапором боротьби сексуальних меншин за свої права, й сьогодні залишається чимало проблем у даній сфері. Враховуючи, що права людини за ознаками сексуальної ідентичності переважною мірою порушуються саме на локальному рівні: адже життєвим простором існування цієї категорії людей є, насамперед, територіальна громада, - питання прав сексуальних меншин об'єктивно може розглядатися і в аспекті формування та реалізації муніципальних прав людини. Свідченням тому $є$, зокрема, позиція Конгресу місцевих і регіональних влад Ради Європи, який звернув увагу на необхідність подолання проблеми дискримінації сексуальних меншин. Відповідно до позиції даної установи, гомофобні інциденти у ряді держав-членів свідчать не 
тільки про систематичні порушення основних прав ЛГБТ, а і показують, що в багатьох випадках органи влади, на які покладено позитивний обов'язок захисту громадян від дискримінації, фактично заохочують несправедливість та сприяють неправомірному обмеженню прав. На запобігання та протидію дискримінації у державах-членах Ради Європи 2007 р. Конгресом було прийнято Рекомендацію 211(2007) «Про свободу зборів і висловлювання думок для лесбійок, геїв, бісексуалів і трансгендерних осіб» [39]. Враховуючи, що свобода вираження думки і свобода зборів $\epsilon$ ядром демократичного суспільства і що роль влади у захисті цих прав $є$ фундаментальною, Конгрес місцевих і регіональних влад Ради Європи запропонував модель імплементації цих прав на місцевому рівні держав-членів без дискримінації за ознакою сексуальної орієнтації та гендерної ідентичності. Як зазначається у даних Рекомендаціях, право висловлювати думку та виражати свою ідентичність 3 іншими людьми $\epsilon$ невід'ємною частиною толерантності - принципу захисту різноманітності суспільства шляхом вільного обміну ідеями, які можуть привести до збагачення на рівні індивіда та суспільства. Ці свободи, природно, несуть 3 собою певні обов'язки і відповідальність і, тому, як держава, так і регіональні або місцеві органи можуть встановлювати обмеження тільки там, де вони передбачені законом. Беручи до уваги, що свобода слова i зібрань лежить в основі демократичного суспільства, а також те, що роль місцевої влади в підтримці цих прав має основоположне значення, Конгрес місцевих і регіональних влад здійснив огляд реалізації цих прав на місцевому рівні по всій Європі та рекомендував країнам-членам Ради Європи забезпечити, щоб вони публічно виступали проти дискримінації за ознакою належності до сексуальних меншин; здійснювали заходи щодо боротьби 3 пропагандою ненависті на даному грунті, з усією строгістю розслідували усі випадки насильства або розпалювання ненависті щодо ЛГБТ, визначали, чи $є$ ці дії дискримінацією 
або гомофобією, можливо, зіграли певну роль у вчиненні злочину, забезпечували судове переслідування винних; в разі необхідності здійснювали позитивні заходи відповідно до вимог Європейського суду 3 прав людини; щоб гарантувати реалізацію свободи зібрань і висловлювання як на державному, так і місцевому та регіональному рівнях; забезпечували можливості ЛГБТ-груп проводити консультації при реформуванні будь-якого з вищевказаних заходів з точки зору взаємної вигоди всіх зацікавлених сторін і розвивали дух співпраці, а не конфронтації. Конгрес звернув увагу на те, щоб усі місцеві влади були в курсі всіх нових законодавчих норм і відповідного прецедентного права, що стосується свободи зібрань i висловлення думок i антидискримінаційних заходів. На думку Конгресу, надання фінансової або іншої підтримки з боку місцевої влади організаторам заходів ЛГБТ-спільноти має бути забезпечене в рівній мірі щодо всіх подібних груп, при цьому не повинно бути ніяких законодавчих заборон місцевим органам влади, які надають допомогу або рекламують події ЛГБТ-спільноти тощо.

Зазначені приклади значною мірою вказують на місце та роль місцевого самоврядування у процесах глобалізації, міжнародної міждержавної інтеграції та формування сучасного конституційного гуманітарного права. Муніципальні права людини та дієздатне місцеве самоврядування $\epsilon$ одним 3 тих атрибутів сучасного конституціоналізму та соціально-правової демократичної державності, що, у контексті європейського вектору розвитку української держави, вимагає свого усебічного конституювання та інституціоналізації на принципах гуманізму, людського виміру публічної влади та верховенства права.

\section{Висновки}

1. Концептуально-конституційний аналіз прав людини у місцевому самоврядуванні свідчить, що вони входять до 
категорії загальних конституційних прав громадян, а тому і до загальної конституційної правосуб'єктності. Однак, реалізація даного виду прав викликає до життя спеціальну правосуб'єктність особи - муніципальну правосуб'єктність, яка включає муніципальну правоздатність і, відповідно, муніципальну дієздатність та муніципальну деліктоздатність людини у сфері місцевого самоврядування. Фактично загальні конституційні права у місцевому самоврядуванні трансформуються у спеціальні суб'єктивні права та обов'язки, характеризувати які можна лише 3 урахуванням мети вступу особи у правовідносини у сфері місцевого самоврядування та їх об’єкта - питань місцевого значення. Важливо при цьому враховувати, що конкретні форми і механізми взаємодії (а часом і взаємопроникнення) інститутів основних прав та свобод людини і громадянина 3 інститутами місцевого самоврядування можуть бути різні.

2. Концептуальний аналіз системи конституційних прав та свобод людини i громадянина у зіставленні із муніципальним рівнем їх можливої реалізації, а іноді і захисту, пояснюється прагненням показати особливе місце та роль у цій системі прав та свобод людини і громадянина у сфері місцевого самоврядування. Це специфічний, обумовлений як способом нормативної фіксації, так i механізмами реалізації, комплекс прав та свобод людини і громадянина, який включає загальновизнані та конституційно закріплені права та свободи, але такі, що реалізуються у межах території, на яку розповсюджується юрисдикція відповідної територіальної громади та такі, що мають своєю метою організацію та здійснення місцевого самоврядування на демократичній основі із використанням конституційно-правових інститутів.

3. В умовах глобалізації та модернізації національної державності форми і механізми взаємодії інститутів основних прав та свобод людини i громадянина 3 інститутами місцевого самоврядування багато у чому визначаються не тільки самобутніми традиціями розвитку 
місцевого самоврядування, специфікою історичних умов його становлення, особливостями поєднання в даному інституті індивідуально-особистісних і колективістських начал, а і відповідними процесами транснаціоналізації конституційного та муніципального права.

\section{Список використаних джерел:}

1. Wheeler N. J. Pluralist and Solidarist Conception of International Society: Bull and Vincent on Humanitarian Intervention. Millennium: Journal of International Studies. 1992. № 21. P. 463-489.

2. Foreign Policy and Human Rights. Issues and Responses / ed. by R. J. Vincent. Cambridge: Cambridge University Press, 1986. 283 p.

3. Donnelly J. Human Rights: a new standard of civilization? International Affairs. 1998. Vol. 74. № 1. P. 1-23.

4. Foreign Policy and Human Rights. Issues and Responses / ed. by R. J. Vincent. Cambridge: Cambridge University Press, 1986. 283 p.

5. Горбатенко В. П. Громадянськість. Юридична енциклопедія: в 6 т. / [редкол.: Ю. С. Шемшученко (голова) та ін.]. Київ: Вид-во «Українська енциклопедія» імені М. П. Бажана, 1998-2004. Т. 1: А-Г. 1998. 672 с.

6. Гареева Л. Г. Институт гражданственности: сравнительный социологический анализ городов разной людности (на примере городов Урала): автореф. дис. на соискание учен. степени канд. социол. наук: спец. 22.00.04 «Социальная структура, социальные институты и процессы». Екатеринбург, 2008. 19 с.

7. Еремин А. Р. Реализация права человека и гражданина на местное самоуправление в Российской Федерации: Конституционные вопросы: автореф. дис. на соискание учен. степени доктора юрид. наук: спец. 12.00.02 «Конституционное право; муниципальное право». Саратов, $2003.58 \mathrm{c}$.

8. Батанов O. В. Муніципальна влада та проблеми співвідношення колективізму, індивідуалізму та автономії 
особистості у місцевому самоврядуванні. Формування правової держави в Україні: проблеми $і$ перспективи: матеріали IX Всеукраїнської наук.-прак. конф. (м. Тернопіль, 13 квітня 2007 р.). Ч. І. Тернопіль: Економічна думка, 2007. C. 209-215.

9. Бондарь Н. С. Гражданин и публичная власть: Конституционное обеспечение прав и свобод в местном самоуправлении: учеб. пособие. Москва: ОАО «Издательский дом "Городец"», 2004. 352 с.

10. Зайцева I. О. Конституційно-правове забезпечення статутної нормотворчості у місцевому самоврядуванні в Україні: автореф. дис. на здобуття наук. ступеня канд. юрид. наук: спец. 12.00.02 «Конституційне право; муніципальне право». Маріупольський державний університет. Маріуполь, 2013. 22 с.

11. Рекомендація Конгресу місцевих і регіональних Влад Європи 280(2010) про роль місцевих і регіональних органів влади в дотриманні прав людини (переглянута) від 19 жовтня 2011 року. Досвід децентралізації у країнах Європи: зб. док. Пер. з іноз. мов. Заг. ред. В. Б. Гройсмана. Київ: Інститут законодавства Верховної Ради України, 2015. 766 c.

12. Декларація щодо забезпечення доброго врядування на місцевому і регіональному рівнях, ухвалена на 14-й сесії Європейської Конференції міністрів держав-членів Ради Європи, відповідальних за регіональне та місцеве врядування (м. Будапешт, Угорська Республіка, 24-25 лютого 2005 року). Збірник "Досвід впровадження стандартів доброго врядування на місцевому рівні в Україні та інших європейських країнах». В. С. Куйбіда, В. В. Толкованов. Київ, ТОВ «Поліграфічний Центр «Крамар», 2010. 258 с.

13. Європейська Хартія місцевого самоврядування. Страсбург, 15 жовтня 1985 року. Сайт Верховної Ради України. URL: http://zakon2.rada.gov.ua/laws/show/994_036

14. Всесвітня декларація місцевого самоврядування 1985 р. Ріо-де-Жанейро, 23-26 вересня 1985 року. Переклад 
3 англійської Ірини Дроздовської. Місцеве та регіональне самоврядування України. Вип. 1-2 (6-7). Київ, 1994. С. 65-69.

15. Європейська рамкова конвенція про транскордонне співробітництво між територіальними общинами або властями. Мадрід, 21 травня 1980 року Сайт Верховної Ради України. URL: http://zakon2.rada.gov.ua/laws/show/ 995_106

16. Всемирная хартия местного самоуправления. Проект. Найроби, 8-12 мая 2000 года. URL: www.un.org/russian/documen/gadocs/25spec/crp7.doc

17. Декларация о принципах местного самоуправления в государствах-участниках Содружества. 29 октября 1994 года. Информационный бюллетень Межпарламентской Ассамблеи государств-участников Содружества Независимых Государств. 1995. № 6. С. 85-89.

18. Стамбульская декларация по населенным пунктам. Стамбул, 14 июня 1996 г. Сайт Верховної Ради України. URL: http://zakon4.rada.gov.ua/laws/show/995_508

19. Екологічна Угода Міст. Підписана 3 нагоди Всесвітнього Дня Довкілля проведеного в рамках Екологічної програми Організації Об’єднаних Націй 5 червня 2005 року у Сан-Франциско, Каліфорнія. Офіційний інтернет-сайт Київської міської ради. URL: http://kmr.gov.ua/divinfo.asp?Id=241

20. Аналіз вразливості жінок та чоловіків в контексті децентралізації на територіях України, що постраждали від конфлікту. Нікого не залишити осторонь. Звіт. Вересень 2017. Підготовлений у рамках спільної програми ПРООН та ООН Жінки «Відновлення управління та сприяння примиренню в постраждалих від кризи громадах України». 72 с.

21. Суслова І. Участь жінок в Українській політиці. Вісник Центральної виборчої комісії. 2016. № 2 (34). С. 18-19.

22. Гендерна рівність у місцевому політичному житті та гендерна концепція у місцевій політиці в Україні. Документ до обговорення підготовлений п. Вишнею Бачановіч, консультантом 3 гендерної рівності за координації Департаменту співробітництва та зовнішніх відносин 
Секретаріату Конгресу місцевих та регіональних влад Ради Європи. Лютий 2018. 38 с.

23. Гендерний моніторинг виборів. Молодий вік для чоловіків - перевага, а для жінок - недолік. Жінки у політиці, 2 листопада 2015 p. URL: http://vybory2012.wcunetwork.org.ua/Gendernii_montoring_viborv_Molodii_vk_dlja_c holovkv_-_perevaga_a_dlja_zhnok_\%E2\%80\%93_nedolk

24. Семра Амет. Сприяння гендерній політиці в діяльності асоціацій та органів місцевої влади. Кращі практики Спілки асоціацій місцевих органів влади південносхідної Європи (NALAS) URL: https://www.auc.org.ua/sites/ default/files/semra_nalas_-_gender_mainstreaming_at_local_ level_upd_ukr.pdf

25. Декларация о городах и других населенных пунктах в новом тысячелетии: Принята резолюцией S-25/2 специальной сессии Генеральной Ассамблеи от 9 июня 2001 года. Сайт Верховної Ради України. URL: http://zakon.rada.gov.ua/laws/show/ru/995_849

26. Всемирная декларация Международного союза местных органов власти (МСМОВ) о роли женщин в местном самоуправлении (Зимбабве. 1998 г.). Участие женщин в руководстве городами. URL: http://www.owl.ru/win/docum/un/habitat/declar.htm

27. Гендерний підхід: Концепція, методологія та презентація кращих практик, Рада Європи, 2014 р., м. Страсбург, с. 41. URL: https://rm.coe.int/1680596135

28. Рекомендація 148 (2004) про гендерний підхід на місцевому та регіональному рівнях: стратегія сприяння рівності між жінками та чоловіками в містах та регіонах. Конгрес місцевих та регіональних влад Ради Європи, 27 травня 2004 рік. URL: https://rm.coe.int/168071a54

29. Резолюція 176 (2004) про гендерний підхід на місцевому та регіональному рівнях: стратегія сприяння рівності між жінками та чоловіками в містах та регіонах. Конгрес місцевих та регіональних влад Ради Європи, 27 травня 2004 рік. URL: https://rm.coe.int/16807191f2 
Права людини в Україні та у зарубіжних країнах:

проблеми теорії та нормативно-правової регламентації

30. Резолюція 405(2016) та Пояснювальний меморандум про гендерне бюджетування, CG 31(2016)10 final, Комітет управління Конгресу місцевих та регіональних влад Ради Європи, 21 жовтня 2016 р. URL: https://rm.coe.int/1680718ce9

31. Резолюція 391(2015) про боротьбу із зростаючою бідністю серед жінок: відповідальність місцевих та регіональних органів влади, Конгрес Ради Європи, 21 жовтня 2015 p. URL: https://rm.coe.int/16807199f1

32. Європейська хартія рівності жінок і чоловіків у житті місцевих громад, Рада Європейських муніципалітетів та регіонів, травень 2006 рік, м. Інсбрук. URL: http://www.ccre.org/docs/charte_egalite_en.pdf

33. Аналітичний звіт «Децентралізація та місцеве врядування як потенціал гендерної рівності» (Заключний). Підготовлений БФ «Інтелектуальна перспектива». Київ, 2011. С. 37-38.

34. Баймуратов М. Місцеве самоврядування як фактор інтернаціоналізації національного та конституціоналізації міжнародного правопорядків. Юридичний журнал: Аналіт. матеріали. Коментарі. Судова практика. 2011. № 12. C. 24-31.

35. Сарновська С. О. Сучасна соціальна комунікативна культура (філософсько-методологічний аналіз): автореф. дис. на здобуття наук. ступеня канд. філос. наук : спец. 09.00.03 «Соціальна філософія та філософія історії»; Ін-т філос. ім. Г.С. Сковороди НАН України. Київ, 2000. 18 с.

36. Європейська ландшафтна конвенція. Флоренція, 20 жовтня 2000 року. Сайт Верховної Ради України. URL: http://zakon4.rada.gov.ua/ laws/show/994_154

37. Переглянута Європейська Хартія щодо участі молоді у громадському житті на місцевому та регіональному рівнях. Прийнята Конгресом місцевих та регіональних влад Ради Європи на 10-й пленарній сесії 21 травня 2003 р. Збірник "Досвід впровадження стандартів доброго врядування на місцевому рівні в Україні та інших 
Права людини в Україні та у зарубіжних країнах:

проблеми теорії та нормативно-правової регламентації

європейських країнах». В. С. Куйбіда, В. В. Толкованов. Київ, ТОВ «Поліграфічний Центр «Крамар», 2010. 258 с.

38. Конвенція про права осіб з інвалідністю. ГА ООН, 13 грудня 2006 p. Сайт Верховної Ради України. URL: http://zakon3.rada.gov.ua/laws/show/995_g71/page

39. Європейська конвенція про участь іноземців у суспільному житті на місцевому рівні. Страсбург, 5 лютого 1992 року. Сайт Верховної Ради України. URL: http://zakon3.rada.gov.ua/laws/show/994_318

40. Recommendation 211 (2007) Freedom of assembly and expression for lesbians, gays, bisexuals and transgendered persons. The Congress of Local and Regional Authorities. URL: https://wcd.coe.int/ViewDoc.jsp?id=1099699\&Site=Congress. 